\title{
Finanspagten og issue-linkage inden for eurosystemet
}

\author{
Derek Beach
}

Lektor, Institut for Statskundskab, Aarhus Universitet

Valutaunioner kan ikke fungere, uden at finanspolitisk kontrol og overførsler følges ad. Vi kan ikke forstå forhandlingerne om Finanspagten uden at forstå, at der her sker en sammenknytning mellem kontrol- og overførselsmekanismer, som vil være bestemmende for eurosystemets fremtidige virkemåde.

\section{Introduktion}

Denne artikel argumenterer, at vi ikke kan forstå Finanspagten og dens vedtagelse i starten af 2012, uden at den ses som en del af en større forhandling om at reformere eurosystemets virkemåde, hvilket på sigt også vil resultere i en form for permanent overførselsmekanisme mellem landene i eurozonen. Læren fra andre valutaunioner som Canada og USA er, at uden både stærke regler for, hvordan delstaterne skal opføre sig finanspolitisk, og en vis form for overførsel mellem de mere eller mindre konkurrencedygtige delstater vil unionen have svært ved at overleve på længere sigt, når asymmetriske chok rammer de mere ukonkurrencedygtige delstater.

Landene inden for eurozonen kan groft sagt deles i vindere og tabere af valutaunionen. ${ }^{1}$ Lande med vedvarende overskud på betalingsbalancen pga. en stigende relativ konkurrenceevne inden for eurosystemet vinder, mens taberne er lande med underskud pga. ringere konkurrenceevne. Disse økonomiske positioner medfører modsatrettede præferencer i forhold til reformer af eurosystemet. En euro-vinder som Tyskland har haft en stærk interesse $i$ at stabilisere eurosystemet bl.a. ved at indføre stærkere regler og disciplin for at undgå, at systemet bryder sammen, eller at de hæfter for gælden i nogle af de gældstyngede euro-taberlande som Italien eller Spanien. Til gengæld har euro-taberne stærke interesser $i$ at sikre en slags kollektivisering af den offentlige gæld inden for eurozonen eller andre former for overførsler for at kompensere for deres tab af den relative konkurrenceevne til især Tyskland. ${ }^{2}$

Hver for sig vil det være vanskeligt at opnå en aftale om de to emner. Ved at binde de to emner sammen i en større (og langstrakt) 'noget for noget'-forhandling, hvor forskellige former for overførsler, f.eks. en bankunion, er på bordet, er det lykkedes at få gennemført større reformer af euro-reglerne i 2011-12, end der ellers vil have fundet sted. Euro-taberne har accepteret strengere regler for landenes finanspolitiske opførelse, end de ellers ville være gået med til pga behovet for tysk accept af flere og større overførelsesmekanismer, som kan hjælpe dem igennem deres økonomiske kriser. Til gengæld har Tyskland accepteret flere og større overførsler, end de ellers ville, pga denne 'noget for noget'-aftale, men også fordi eurotaberne kunne udnytte presset fra finansmarkederne til at argumentere for, at uden flere overførsler vil euroen bryde sammen. Derfor er det ikke overraskende, at når markedspresset er begyndt at lette i løbet af efteråret 2012, er forhandlinger om flere overførsler også gået i stå.

Artiklen beskriver først, hvad vi ved ud fra teorien om, hvornår issue-linkage virker, og hvilke effekter den kan have i en forhandling. Derefter vil artiklen undersøge, om der er beviser på, at issue-linkage har fundet sted. Først undersøges det, om parterne havde forskellige (he- 
terogene) præferencer, og derefter hvorvidt de to emner er funktionelt afhængige af hinanden ved at sammenligne erfaringer fra andre valutaunioner. Dernæst beskrives forhandlingssituationen om reformerne af eurosystemet efter finanskrisens begyndelse i 2010 med fokus på de to koalitioner (vindere og tabere), og hvilke former de to emner har taget inden for EU. Der fokuseres på, om der er stærke beviser for, at issue-linkage har fundet sted mellem de to emner, og, i givet fald, hvilke implikationer denne sammenkobling har haft for partnernes muligheder for at opnå deres interesser.

\section{Teori - issue-linkage og afhængighed mellem forskellige emner}

Kort fortalt betyder issue-linkage, at to (eller flere) emner forbindes i en forhandling således, at en aftale ikke kan opnås, uden at begge emner er løst, hvilket kan have både positiv og negativ betydning for forhandlingens resultater. Hvis det lykkes at forbinde to emner, som det hver for sig er umuligt at opnå en aftale om, og hvor parterne har forskellige præferencer i de to emner, kan issue-linkage åbne for en pakkeløsning, som muliggør en samlet aftale. Sebenius beskriver, hvordan forhandlingerne om FN's havretskonvention var strandet pga. uenigheder mellem de udviklede og udviklingslandene om to emner, hvor parterne havde modsatrettede præferencer (1983: 293294). Ved at forbinde de to emner kunne der laves en 'noget for noget'-pakkeaftale, som begge parter foretrak frem for ingen aftale (ibid). Helt modsat er situationen, hvor to (eller flere) emner forbindes, men hvor kombinationen besværliggør eller umuliggør en samlet løsning.
Bedste eksempel herpå er fredsforhandlingerne mellem Palæstina og Israel, hvor det meget følsomme nul-sumsissue om Jerusalems status forbindes med andre emner. At ingen af parterne vil gå på kompromis om Jerusalem, har gentagne gange forhindret en samlet aftale.

Effektiv issue-linkage illustreres i figur 1, hvor to parters nytte ift. to emner er afbildet. Her ser vi, at emne 1 og 2 ikke har adskilte forhandlingszoner. I emne 1, hvor forhandlingerne vil finde sted på linjen A-SQ, vil aktør 2 altid foretrække status quo, SQ (ingen aftale) frem for enhver bevægelse hen imod aktør 1's foretrukne position (A), og modsat i emne 2. Men ved at forbinde de to emner opstår der en forhandlingszone, hvor punkt $\mathrm{C}$ er det mest sandsynlige resultat, som begge aktører foretrækker frem for SQ.

Hvornår lykkes issue-linkage, og hvornår ikke? Inden for forhandlingslitteraturen peges der særligt på to faktorer, som skal være til stede for at issue-linkage kan have positive effekter: a) heterogene præferencer og b) afhængighed mellem emnerne (funktionelt og/eller opfattet). Issue-linkage virker ikke, når parterne har ensartede præferencer (Conceicao-Heldt, 2008), og når parter, som er imod linkage, foretrækker ingen aftale frem for linkage (Moravcsik, 1998: 60, 62).

Heterogene præferencer betyder, at parterne tillægger emner forskellige værdier (nytte) (Sebenius, 1983: 293294; Conceicao-Heldt, 2008). For eksempel, hvis aktør A tillægger emne 1 en positiv værdi (positiv nytte), og aktør B foretrækker ingen aftale frem for en aftale i emne 1 (negativ nytte), og omvendt i emne 2, vil en sammenkobling af de to emner potentielt kunne skabe en pak-

Figur 1 - Positiv issue-linkage

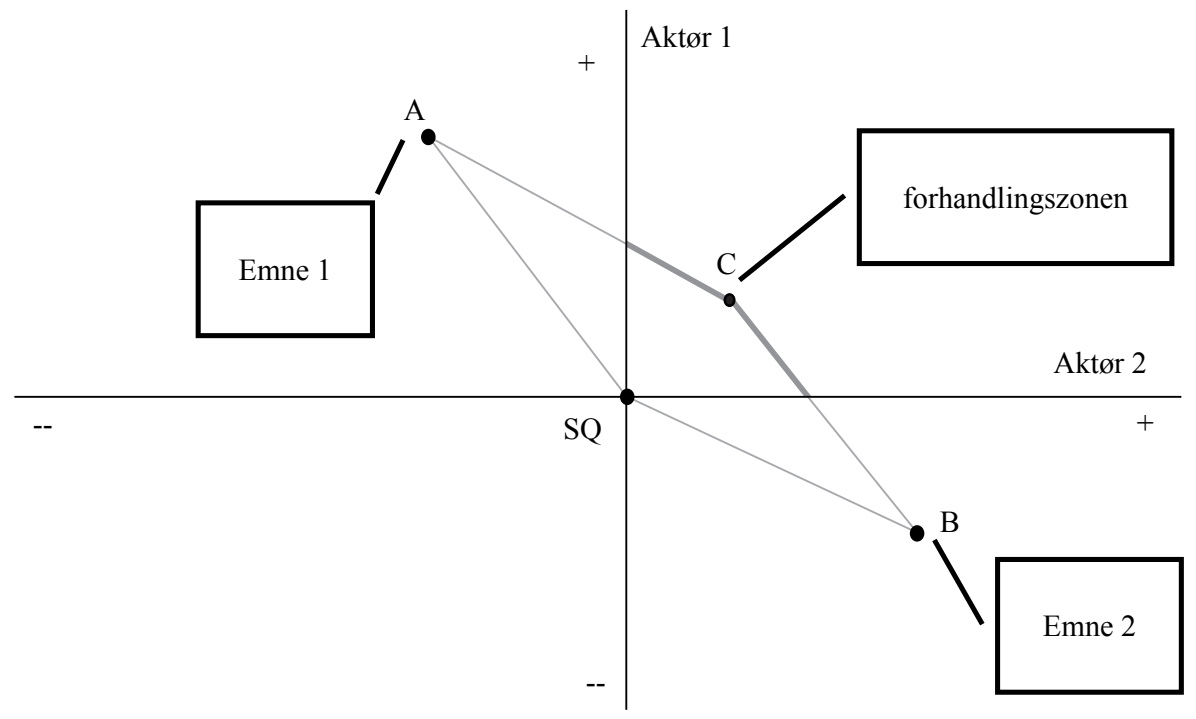


keløsning, så begge parter får positiv nytte i forhold til ingen aftale. Det forudsættes naturligvis, at begge parter får større positiv end negativ nytte af det andet emne; ellers vil en pakkeløsning ikke give positiv nytte for begge parter. Hvis pakkeløsningen ikke giver positiv nytte, vil en rationel aktør foretrække ingen aftale.

Den anden faktor, som gør issue-linkage mere effektiv, er, at de to emner opfattes som afhængige af hinanden (Susskind, 1994) ofte pga. en funktionel afhængighed mellem dem. Funktionel afhængighed defineres som en objektiv forbindelse mellem emner, hvor f.eks. en aftale om det ene emne ikke kan lade sig gøre, uden at der også findes en løsning på det andet. Der behøver ikke nødvendigvis altid at være en objektiv forbindelse (ibid, s. 92), men begge parter skal opfatte, at der eksisterer en vis form for afhængighed mellem de to emner, for at opnå en løsning (Betts, 2008). Issue-linkage viser sig derfor at være mest effektiv, når parterne opfatter en samlet pakkeløsning af de to emner som meget naturlig.

Hvordan kan vi undersøge, om issue-linkage har fundet sted i forhandlingerne om at reformere eurosystemet? Hvilke empiriske beviser vil vi forvente at finde, hvis tesen om positiv issue-linkage mellem disciplin/regler og overførsler er rigtig, og hvad vil svække vores tillid til tesen?

I afsnit 3 undersøges, hvorvidt parterne havde heterogene præferencer i spørgsmålet om at reformere eurosystemet. Her ses der især på landenes makroøkonomiske position, hvor både deres relative konkurrenceevne og de deraf afledte effekter på betalingsbalancen undersøges. Lande, der har 'vundet' ved eurosystemet, defineres som lande, der har overskud på betalingsbalancen og har opnået en relativt stærk konkurrenceevne i forhold til andre eurolande og i modsætning til 'taberne'. Vi vil også forvente at se, at forslag fra de to grupperinger afspejler deres relative position. Euro-vinderne vil foreslå stærkere regler for finanspolitisk opførsel, mens euro-taberne vil foreslå, at der bliver oprettet mekanismer, der flytter penge fra de konkurrencedygtige til de ikke-konkurrencedygtige lande.

I afsnit 4 undersøges, hvorvidt der var funktionel afhængighed mellem de to emner. Først ses der på, om der er funktionel afhængighed mellem de to emner i andre valutaunioner. Funktionel afhægighed i forhold til valutaunioner kan defineres som, hvorvidt valutaunionen er robust over for asymmetriske chok uden at både disciplin og overførsler er til stede. Naturligvis skal man være påpasselig med at sammenligne føderale stater med EU, men teorien om Optimal Currency Areas (OCA) tilsiger, at der ikke er forskel mht. de udfordringer, som delstaterne møder, når der opstår asymmetriske chok. Asymmetriske chok er økonomiske kriser, der rammer regioner eller bestemte delstater hårdere end andre dele af valutaunionen.

Hvis historiske erfaringer viser, at både disciplin og overførsler skal være til stede for at stabilisere systemet efter asymmetriske chok, kan det forsigtigt konkluderes, at der er funktionel afhængighed mellem de to emner. I forhold til selve eurosystemet vil en indikator for funktionel afhængighed være det pres, der kommer fra finansmarkederne på systemet i en situation, hvor asymmetriske chok er til stede, men hvor kun det ene emne forhandles. En mere direkte indikator er, at under- og overskud på betalingsbalancerne inden for valutaunionen skaber de facto økonomiske overførsler mellem landene (enten midlertidige eller af mere permanent karakter). Her ses der særligt på bevægelserne mellem nationalbankerne inden for Target-systemet.

Indikatorerne for funktionel afhængighed betyder ikke nødvendigvis, at begge parter opfatter, at der er en afhængighed mellem emnerne, som gør, at de ikke kan løses hver for sig. Derfor undersøges det i afsnit 5, hvorvidt vi kan finde tegn på, at issue-linkage har fundet sted. Men hvilke empiriske fingeraftryk vil vi forvente, issuelinkage efterlader? En rygende pistol vil være et bevis på, at begge emner kædes direkte sammen i de officielle dokumenter fra forhandlingen, som f.eks. i topmødeerklæringer. En anden rygende pistol kunne være, at fremtrædende repræsentanter fra begge sider fremhæver forbindelsen i deres udtalelser og taler. Desværre betyder fraværet af denne eksplicitte issue-linkage ikke nødvendigvis, at parterne ikke har opfattet, at de to emner er forbundne. Der kan f.eks. være indenrigspolitiske grunde til, at en eller begge parter ikke har lyst til at offentliggøre en forbindelse mellem de to emner. Hvis dette er tilfældet, vil en svagere form for bevis blot være, at de to emner forhandles samtidigt.

\section{Heterogene præferencer - euro-vindere og -tabere}

Havde parterne heterogene præferencer i forhandlingerne om reformer af eurozonen? Her er der to emner: indførelse af strengere regler for landenes finanspolitisk opførsel, og flere/større midligertidige eller permanente overførsler.

Overordnet kan euro-landene deles op i to grupper: de lande, som har opnået en relativt stærk konkurrenceevne i forhold til EU-gennemsnittet, og de lande, som har mistet konkurrenceevnen (se tabel 1). 
Tabel 1 - Udvalgte økonomiske indikatorer for fire euro-lande

\begin{tabular}{|l|cc|ccc|}
\hline & \multicolumn{2}{|c|}{ Euro-vindere } & \multicolumn{3}{c|}{ Euro-tabere } \\
\hline & Tyskland & NL & Frankrig & Spanien & Italien \\
\hline Relative Iønomkostninger i 2011 (1999=100) & 91,5 & 97,2 & 95,7 & 114,1 & 121,6 \\
\hline Betalingsbalance i 2012 i \% af BNP & 5,4 & 9,0 & $-1,9$ & $-0,9$ & $-2,2$ \\
\hline Budgetunderskud i \% af BNP i 2011 & $-0,8$ & $-4,5$ & $-5,2$ & $-9,4$ & $-3,9$ \\
\hline Offentlig gæld i \% af BNP i 1.kvartal af 2012 & 81,6 & 66,8 & 89,2 & 72,1 & 123,3 \\
\hline Økonomisk vækst i \% af BNP (2012) & 0,8 & $-0,3$ & 0,2 & $-1,4$ & $-2,3$ \\
\hline Landets balance inden for ECB-systemet (Target) & $€ 463$ mia & $€ 155$ mia & $-€ 69$ mia & $-€ 175$ mia & $-€ 191$ mia \\
\hline Arbejdsløshed (3. kvartal 2012) & $6,9 \%$ & $6,6 \%$ & $10,8 \%$ & $25,8 \%$ & $10,8 \%$ \\
\hline
\end{tabular}

Kilde: Eurostat (lønomkostninger, offentlig gæld, økonomisk vækst); OECD (betalingsbalance); og Sinn og Wollmershäuser, 2012 : 470 (Target-balancer); Economist 10-16.11.12 (arbejdsløshed).

Hvis vi bruger de relative lønomkostninger i fremstillingsindustrien i forhold til andre eurolande som en proxy for konkurrenceevne, ser vi, at euro-kernelande som Tyskland og Holland er blevet 20-30 pct. billigere end periferilande som Italien og Spanien - begge lande har haft en stærk stigning i de relative lønomkostninger i perioden fra 2000 indtil 2011. Denne udvikling genkendes fra 80'erne, hvor periferilandene devaluerede for at genoprette konkurrenceevnen, hvilket var den præcise årsag til, at tysk industri agiterede for euroens indførelse for at kunne høste fordel af deres relativt forbedrede konkurrenceevne (Moravcsik, 1998: 392-393).

Denne reelle devaluering var medvirkende til en stærk stigning i det tyske og hollandske betalingsbalanceoverskud fra 2003-04 indtil 2012, da eksportorienteret produktion blev væsentligt billigere relativt set i forhold til konkurrenterne i periferilandene (Tysklands overskud var på 5,4 pct. af BNP i 2012 og Hollands hele 9 pct.). I modsætning hertil havde særligt Spanien (men også Frankrig) et meget stort underskud indtil 2011, men pga. den økonomiske krise er importen faldet drastisk, hvilket viser sig ved en vis forbedring af betalingsbalancen i 2012. Frankrig er et lidt specielt tilfælde blandt eurotaberne, da de ikke oplevede de samme lønstigninger som andre euro-tabere, men alligevel har de underskud på betalingsbalancen og et forholdsvis stort underskud på de offentlige finanser pga. tab på andre parametre, som påvirker konkurrenceevnen ift. Tyskland (World Bank, 2012; IMF, 2012).

Forskellen i konkurrencevnen afspejles også i væksttallene, hvor Tyskland havde en svag vækst i 2012 på trods af euro-krisen, mens Italien og Spanien oplevede økonomisk nedgang. Derfor kan euro-landene lidt forenklet deles op i euro-vindere og -tabere. En mere direkte effekt af betalingsbalancen er de forskellige centralbankers nettobalance inden for ECB-systemet (Target balancen), hvor f.eks. den tyske centralbank har oparbejdet et meget stort overskud pga. forskellen mellem, Tysklands fortje- neste og betaling i handlen med andre euro-lande (dvs. betalingsbalancen) (Sinn og Wollmerschäuser, 2012).

Landenes økonomiske position som enten vindere eller tabere målt ift. betalingsbalancen påvirker også deres præferencer i forhold til reformering af eurosystemet. Mens der er flere grunde til eurokrisen, mener mange forskere, at hovedårsagen er den strukturelle ubalance der skabes pga. for store over-/underskud på betalingsbalancen euro-landene imellem, mens de mere kortsigtede gældsproblemer, som bl.a. Irland og Spanien kom ud i efter bankkriserne, mere har karakter af at være medvirkende årsager, som forværrede de grundlæggende problemer (f.eks. Eichengreen, 2012; Sinn og Wollmerschäuser, 2012; EEAG, 2012).

Grundet de høje økonomiske omkostninger ved et sammenbrud af euroen er ingen af landene interesserede i et kollaps, og derfor er både vindere og tabere interesseret i forhandlinger, som skal føre til et mere stabilt system. ${ }^{3}$ Dette er vigtigt for at forstå, hvorfor det lykkedes eurotaberne at presse Tyskland (og andre euro-vindere) til at acceptere issue-linkage. De kunne argumentere, at uden øget hjælp i form af overførsler vil de gå konkurs, med det sandsynlige resultat at euroen vil bryde sammen - hvilke vil påføre Tyskland store økonomiske tab.

Landenes præferencer ift. de to emner bestemmes af deres relative konkurrenceevne og betalingsbalanceover-/ underskud. Euro-vinderne (overskudslandene) mener overordnet, at krisen skyldes periferilandenes overforbrug i de offentlige og private sektorer. På kortere sigt er løsningen i deres øjne nedskæringer i de offentlige budgetter og strukturreformer for at bringe kriselandene i en stabil finansiel position, så de kan genvinde deres relative konkurrenceevne. Samtidig har overskudslandene en klar egeninteresse $\mathrm{i}$, at de ikke kommer til at betale regningen for underskudslandenes låntagning, som har været brugt til at finansiere deres merimport og de højere offentlige udgifter som følge af de økonomiske problemer, underskuddet har medført. Ifølge Tyskland indebærer dette f.eks., at hjælp til kriselandene kun skal ydes via meget 
midlertidige lån gennem ESM (European Stability Mechanism) eller ECB's markedsoperationer pålagt strenge krav for at undgå, at markedspresset, som kan tvinge dem til at lave reformer og nedskæringer, bliver lettet (Dullien og Guérot, 2012). Man vil gerne hjælpe, det må bare ikke koste noget.

For at undgå at betale regningen på længere sigt ønsker euro-vinderne, at de tyske krav, udmøntet i Maastricht-traktatens forbud mod redninger (no bail-outs), håndhæves. Videre er der ønske om stærkere regler for den finanspolitiske kurs i landene, så det undgås, at eurosystemet kommer i en situation, hvor det skal vælge mellem at lade systemet bryde sammen eller lade overskudslandene betale regningen ved at hæfte for underskudslandenes offentlige gæld, eller ved at skulle overføre penge for at redde det, Tysklands elite opfatter som uansvarlige banker i periferien. Vi ser den tyske position klart udtrykt i Merkels tale til Bundestagen d. 2. december 2011, hvor hun udtalte, at '...Læren er ret enekl: Regler skal overholdes, overholdelse skal overvåges, og manglende overholdelse skal medføre konsekvenser' (egen oversættelse). Derfor vil Tyskland gerne have strenge regler, men kun meget få overførsler, som kun har midlertidig karakter.

Euro-taberne (underskudslandene) er på kortere sigt interesseret $\mathrm{i}$, at markedspresset på dem lettes, således at de har nemmere og billigere adgang til lån for at kunne stimulere deres økonomier og komme ud af den kraftige økonomiske recession, de er fanget i. Samtidig mener de, at hvis der indføres strengere regler for landenes underskud, kan det vise sig at være modproduktivt i krisetider, da der kan opstå en nedadgående spiral med faldende udgifter, der fører til mindre aktivitet og højere arbejdsløshed. Dette resulterer i stigende offentlige udgifter og faldende indtægter, med endnu flere nedskæringer osv. til følge.

Underskudslandenes overordnede opfattelse af det grundlæggende problem er, at euroen har en konstruktionsfejl. Da euroen blev forhandlet i slutningen af 80 'erne, var der en udbredt tro i Frankrig og Italien på, at euroens indførelse ville medføre en økonomisk konvergens mellem landene. De troede, at med konvergens inden for valutaunionen ville de ikke længere skulle slås med konkurrenceevneproblemer i forhold til Tyskland. Det modsatte viste sig at være tilfældet både pga. deres opførsel i euroens første år samt Tysklands unilaterale strukturelle reformer. I starten af 00'erne udnyttede lande som Italien og Spanien ikke de kortsigtede økonomiske gevinster ved indførelsen af euroen til at bringe de offentlige finanser i orden og lave strukturreformer, som kunne opretholde landenes konkurrenceevne. Samtidig førte Tyskland den modsatte politik grundet den krise, landet stod i pga. genforeningen. Der blev f.eks. lavet meget omfattende strukturreformer, som medvirkede til at skabe en endnu større relativ depreciering i Tyskland i forhold til eurotaberne. Finanskrisen og den store stigning i prisen på offentlig gæld i underskudslandene var derfor blot et symptom på den stigende underliggende divergens.

Underskudslandene har derfor en interesse $\mathrm{i}$, at der indføres økonomiske tiltag som kompensation for den manglende konvergens. På længere sigt har disse lande

Figur 2 - Issue-linkage i euro-reform-forhandlingerne

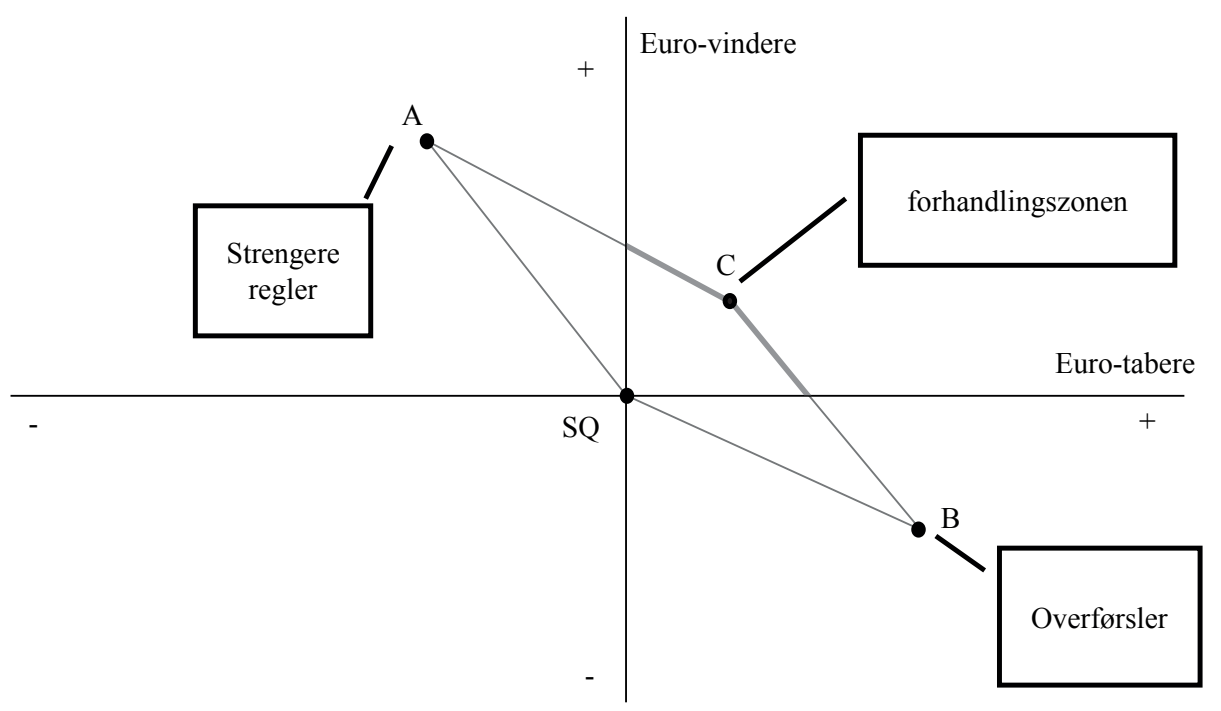


en interesse $i$, at der arbejdes imod en kollektivisering af gæld og andre former for overførsler, som kan hjælpe landene, når de uundgåeligt kommer $\mathrm{i}$ vanskeligheder pga. betalingsbalanceproblemer.

Derved ser vi to helt modsatrettede præferencesæt, når det drejer sig om at reformere euroen. Dette illustreres i figur 2, hvor vi ser, at euro-vinderne ønsker stærkere regler, så risikoen mindskes for, at de kommer til at betale regningen, og euro-taberne ønsker, at forskellige former for overførsler indføres. Hver for sig er der ingen grund til, at partnerne vil acceptere en aftale. F.eks. der er ingen grund til, at euro-taberne accepteret et tysk diktat om strengere regler, uden at Tyskland kan give noget til gengæld i form af flere/større overføresler.

\section{Var der funktionel afhængighed mellem disciplin og overførsler?}

Er der funktionel afhængighed mellem de to emner: reglerne for medlemsstaternes finanspolitiske opførsel og overførsler mellem euro-vindere og -tabere, f.eks. i form af en kollektivisering af medlemsstaternes gæld i euroobligationer?

For at besvare dette spørgsmål er det nødvendigt med en kort introduktion til teorien om 'Optimal Currency Areas' (OCA) (Mundell, 1961; Flemming, 1971; McKinnon, 2004). Hvis en valutaunion er en OCA, betyder det høj grad af økonomisk konvergens uden risiko for, at bestemte lande eller regioner kan blive ramt af asymmetriske chok, f.eks. i form af faldende konkurrencevne.

Hvis unionen ikke er en OCA, er der behov for forskellige tilpasningsmekanismer til at hjælpe de ramte lande eller regioner ud af krisen (Flemming, 1971; Eichengreen, 1990). Hvis der ikke er tilpasningsmekanismer, risikerer de at komme i en nedadgående spiral med stigende arbejdsløshed og armod til følge. I sidste instans kan det føre til, at en delstat i krise bliver udsat for så stærke politiske pres fra utilfredse borgere, at den udtræder af valutaunionen. Dette kunne ske, ved at delstaten for at slette en del af sin gæld vælger at devaluere sin valutakurs, hvilke kun kan lade sig gøre, hvis den udtræder af unionen.

De vigtigste tilpasningsmekanismer til at sikre stabilitet er: 1) et fleksibelt pris- og lønniveau for at genoprette konkurrencevnen; 2) mobil arbejdskraft, der kan flytte til delstater/lande/regioner, hvor det går bedre; eller 3) forskellige former for finansielle overførsler, f.eks. i form af fiskal føderalisme, hvor forbundsniveauet flytter ressourcer fra områder, hvor det går godt, til områder, hvor det går skidt.

Selv i det meget integrerede USA viser erfaringer, at pris- og lønniveauet falder i delstater, der er ramt af et fald i konkurrencevnen, men at dette fald ikke er nok til at motivere firmaer til at flytte produktionen tilbage (Blanchard og Katz, 1992; Eichengreen, 1990). Samtidig fravælger nye firmaer at investere i delstaten, da en delstat i økonomisk krise skærer ned på de offentlige udgifter, hvilket betyder en dårligere infrastruktur i området, alt andet lige. Derfor viser de amerikanske erfaringer, at ubalancer i konkurrenceevnen kan fortsætte i årtier med dertilhørende økonomisk stagnation og høj arbejdsløshed.

Der er to ting, som mindsker de negative sociale effekter af disse vedvarende kriser, der rammer bestemte delstater eller regioner i USA. Først, når arbejdsløsheden er høj i et område, flytter folk væk i stort antal, hvilket mindsker udgiftspresset på delstaten i form af arbejdsløshedsunderstøttelse og lignende udgifter (Blanchard og Katz, 1992). Her viser studier, at der er langt mindre bevæglighed indenfor EU end det tilsvarende er i USA eller andre føderale valutaunioner (Ibid; Eichengreen, 1990).

Men endnu mere vigtigt er det, at der overføres penge fra delstater, hvor det går godt, til delstater, hvor det går skidt. Der er en erkendelse af, at visse delstater og regioner i USA (f.eks. West Virginia) aldrig bliver så konkurrencedygtige som eksempelvis New Jersey eller Delaware. Det kaldes fiskal føderalisme og betyder, at forholdsvis store ressourcer overflyttes mellem de delstater, der har store gevinster ved det fælles amerikanske marked, og de delstater, som taber (Henning and Kessler, 2012: 23-24).

Interstatslige overførsler indførtes i USA under den store depression i 30'erne, da delstaterne ikke alene kunne klare det politiske pres, der opstod pga. den stigende fattigdom og arbejdsløshed (Smith, 2006). Fordelingen af de offentlige udgifter skiftede dramatisk som følge af, at præsident Roosevelt indførte store interstatslige overførsler i denne periode. I 1930 var fordelingen som følger: 20 pct. til delstat, 50 pct. til lokale udgifter og 30 pct. til forbundsniveauet (primært forsvar). I 1940: 50 pct. til føderal, 20 pct. til delstat og 30 pct. til lokale udgifter (Wallis, 1991: 510). Forbundsregeringens udgifter steg fra 3,4 pct. af BNP i 1930 til mellem 8 pct. og 11 pct. af BNP i perioden fra 1934 til 1939 (Historical Tables, Office of Budget and Management).

En alternativ måde for delstaterne til at komme ud af konkurrenceevneproblemerne og de deraf skabte sociale spændinger pga. den økonomiske krise kunne være at låne penge til både at finansiere investeringer i en forbedret infrastruktur og at opretholde sociale udgifter til f.eks. arbejdsløshedsunderstøttelse. Men dette kræver store lån, og inden for en valutaunion med fri kapitalbevægelse vil det hurtigt føre til, at delstaten bliver insolvent. Der vil i forvejen være et højt renteniveau grundet behovet for at lånefinansiere handelsunderskuddet. Øget offentlig låntagning vil derfor føre til en stadig højere og højere rente, hvilket både vil mindske private investeringer (og der- 
med forværre den i forvejen slemme økonomiske krise) og skabe risiko for, at med de meget høje låneomkostninger vil landet ikke være i stand til at betale lånene tilbage og bliver dermed insolvent.

For at undgå, at fællesskabet kommer til at hænge på gælden fra delstaternes overforbrug i forbindelse med asymmetriske chok, har alle valutaunioner strenge regler for, f.eks. hvor mange penge delstaterne må låne. Hvis vi igen ser mod USA, forsøgte mange delstater at forbedre deres infrastruktur igennem låntagning i 1830'erne og 40'erne. Men da flere delstater gik bankerot, meddelte forbundsregeringen, at den ikke ville redde dem, hvilket skabte en 'no bail-out'-præcedens i USA (Wallis, 2005; Gillette, 2012). Samtidig indførte de fleste delstater balancerede budgetregler (Ibid).

Ved at indføre fiskal disciplin på delstatsplan opstår den funktionelle afhængighed mellem regler/disciplin og overførsler. Som beskrevet ovenfor med manglende disciplin kunne delstaterne spendere sig ud af kriser. Men dette skaber et 'moral hazard'-problem med den konsekvens, at delstaterne låner for mange penge i forventning $\mathrm{om}$, at hele unionen kommer til at betale lånet tilbage og ikke kun dem selv (Gillette, 2012). Men med stærk disciplin stiger behovet for overførsler delstater/regioner imellem, da delstaterne risikerer at komme i en nedadgående spiral med stigende politiske og sociale spændinger til følge. Historiske erfaringer viser således, at de to emner er tæt forbundet $\mathrm{i}$ andre valutaunioner (Bordo, Jonung, Markiewicz, 2011).

\section{Etablering af issue-linkage under reformfor- handlingerne af eurosystemet}

Som beskrevet i teoriafsnittet er funktionel afhængighed ikke nok til at skabe issue-linkage. Parterne skal opfatte, at de to emner er forbundet, og acceptere, at de bliver forhandlet som en samlet pakke. Da disse to emner kan forventes at tage en væsentlig anderledes form end i føderale stater som Canada eller USA, vil jeg først diskutere, hvordan de har maniferesteret sig i EU. Derefter ser jeg på, hvorvidt der findes beviser for, at begge parter har accepteret issue-linkage mellem strengere regler/disciplin og øgede overførsler. ${ }^{4}$

Disciplin/regler er kommet til udtryk som stramninger af regler for landenes budgetunderskud inden for Vækst- og Stabilitetspagten (six-pack-lovgivningspakken vedtaget i efterår 2011), og Finanspagten, som er en række lignende bindinger på medlemmernes budgetter, der er vedtaget uden for EU-traktaterne. Overførslerne har haft flere former, men fælles er, at økonomiske ressourcer overføres fra overskuds- til underskudslandene. Dette kan være i form af stiltiende accept af overførsler igennem ECB's markedsoperationer siden maj 2010, f.eks. ved udstedelse af ca $€ 1.000$ mia. i billige lån til banker i underskudslandene i foråret 2012 (New York Times, 31.05.12; Economist, 15.09.12), eller stiltiende accept af de ubalancer, der er opstået inden for Target-systemet, som i realiten har samme effekt som indførelse af kortsigtede euro-obligationer i kraft af, at prisen for låntagning i underskudslandene derved sænkes drastisk (Sinn and Wollmerschäuser, 2012). På længere sigt kan overførsler være i form af en fælles redningsfond eller forsikringsordning, der kan bruges til at rekapitalisere banker i syden, eller euro-obligationer som en enten delvis eller hel kollektivisering af den offentlige gæld i medlemslandene. Fælles for alle disse tiltag er, at der overføres ressourcer fra hvor det går godt (euro-vinderne), til hvor det går skidt (euro-tabere). Underskudslandene får stillet penge til rådighed til en pris, som er billigere end markedsprisen - en difference, som overskudslandene kommer til at betale.

Presset fra finansmarkederne på renteniveauet for statsobligationer i euro-taberne har været stærkt medvirkende til, at en sammenkobling mellem de to emner er lykkedes. Et højt renteniveau afspejler markedets tvivl om, hvorvidt periferilande kan komme ud af den økonomiske krise ved en kombination af offentlige nedskæringer og strukturelle reformer uden samtidig at have hjælp udefra i form af enten midlertidige eller permanente overførsler, som både kunne lette de sociale omkostninger ved reformerne og hjælpe landene med at stabilisere og genoprette deres økonomier. Uden dette pres fra markederne vil det formentlig ikke have lykkedes euro-taberne at få Tyskland til at acceptere sammenkobling mellem overførsler med strengere regler.

Der er klare beviser for, at begge parter anerkendte allerede i løbet af 2010, at bevægelse på det ene emne forudsætter en vis bevægelse på det anden. Da finanskrisen begyndte at bide i euro-taberne i 2009-2010, opstod der et behov for midlertidige hjælpepakker (overførsler) til at redde først Grækenland, derefter Irland og Portugal. Parallelt med dette startede et forløb, hvor regeringer i foråret 2010 bad det Europæiske Råds præsident van Rompuy om at udarbejde nogle forslag til stramninger af reglerne for landenes finanspolitiske opførsel inden for Stabilitets- og Vækstpagten (SVP), hvilke resulterede i et rapport til det Europæiske Råd i efteråret 2010. Men Kommissionen nåede forinden at komme med et forslag om reformer af SVP i September 2010, som dannede grundlag for de videre diskussioner.

Men i løbet af 2011 blev det klart pga stigende markedspres på lande som Italien og Spanien, at euro-landene ikke kunne nøjes med kortsigtede og midlertidige mekanismer, som var allerede vedtaget. Der var et behov for flere og større former for hjælp til at lette markedspresset 
således at de to lande ikke blev insolvent som følge af den stigende rente på statsobligationerne.

I løbet af 2011 begyndte mere seriøse diskussioner af både øget disciplin og flere og større former for overførsler. Kommissionens forslag om reformer af SVP resulterede i den såkaldte 'six-pack'-lovgivningspakke, som blev vedtaget i efteråret 2011. Men der var også tegn på, at de tyske ledere bag lukkede døre var begyndt at acceptere, at man på sigt skulle arbejde hen imod en form for kollektivisering af gælden inden for eurozonen, ellers risikerede man, at euroen kunne bryde sammen på sigt (Spiegel, 24.11.11). Men for at give sig på overførselsemnet havde den tyske regering behov for flere stramninger af reglerne pga. indenrigspolitiske faktorer. Der var i 2011 en stærk offentlig modstand både i den tyske befolkning, i den politiske elite og internt i regeringen. Den tyske regering havde f.eks. lavet en intern undersøgelse af omkostninger ved at indføre euro-obligationer og kom frem til, at det på sigt vil koste op imod €20-25 mia. om året i forhøjet renteudgift for den tyske stat (Spiegel, 22.08.11).

Det var i den kontekst, der opstå en sammenkobling mellem flere stramninger af reglerne i form af vedtagelse af Finanspagten og tysk accept af flere overførsler. Et stærkt bevis var, at Tyskland stiltiende accepterede en sammenkobling mellem stærkere regler og overførsler af forskellige former for kortsigtede tiltag fra ECB, hvilket reddede eurosystemet fra kollaps i efteråret $2011 \mathrm{og}$ hele 2012. I løbet af 2011 og i starten af 2012 steg den skjulte overførsel af ressourcer igennem ECB's såkaldt Targetsystem, hvorved det blev muligt for underskudslandene at finansierer deres import, samtidig med at låneomkostningerne blev holdt nede i landene på trods af kapitalflugten fra disse lande (Sinn og Wollmerschäuser, 2012; Deutsche Bank, 2011; De Grauwe og Ji, 2012).

En anden form for overførsel igennem ECB's markedsinterventioner blev indført i sommeren 2012 med åben støtte fra Tyskland (New York Times, 06.09.12). Her accepterede Tyskland, at ECB var begyndt at opkøbe statsobligationer med kort levetid for at holde underskudslandenes låneomkostninger nede (Spiegel Online, 06.08.12). I ECB’s opkøbsprogram er der eksplicit issue-linkage mellem regler og overførsler, da landene skal acceptere strenge betingelser for, hvordan de opfører sig (nedskæringer og strukturreformer).

Samtidig blev der pga tysk pres forhandlet strammere regler i løbet af 2011 og starten af 2012, resulterende i reformerne af Vækst- og Stabilitetspagten (six-pack) samt Finanspagten. Finanspagten kan opfattes som et tysk diktat, hvor Tyskland fik opfyldt næsten alle sine krav om formen og indholdet af en regel om en national gældsbremse indskrevet i forfatningen eller en form for national lovgivning med lignende styrke (Ludlow, 2012).
Men i forhandlingerne var der et klart 'noget for noget'. I topmødeerklæringen fra december 2011, som startede forhandlingerne, blev det eksplicit indskrevet, at EU på længere sigt skulle arbejde mod dybere økonomisk integration (punkt 7), og at euro-landene skulle arbejde for en hurtigere ikrafttræden af ESM (punkt 13) (EUCO 139/1/11, Rev 1). Både Frankrig og Italien ønskede, at denne permanente redningsfond (ESM) skulle træde i kraft så hurtigt som muligt for at afhjælpe de midlertidige finansieringsproblemer (Spiegel Online, 11.01.12, 24.1.12). Som følge af dette krav blev ESM færdiggjort allerede i januar 2012 parallelt med færdiggørelse af Finanspagten, og quid-pro-quo-aftalen blev meget klar, da tyskerne krævede, at man skulle have underskrevet Finanspagten for at kunne modtage støtte fra ESM (Ibid; Ludlow, 2012).

Da det i løbet af foråret 2012 blev klart, at underskudslandene stadig var under stærkt pres pga. den høje pris på udstedelse af statsobligationer, fortsatte diskussionen om at skabe flere (og større) overførsler for at hjælpe landene foretage tilpasninger i forbindelse med asymmetriske chok. Allerede i januar 2012 skruede den italienske statsminister Monti op for presset mod Tyskland, da han forud for et møde med Merkel sagde, at 'If Italians don't see concrete results from their support of austerity and reform in the foreseeable future, a protest will develop against Europe - and against Germany ... I have demanded difficult sacrifices from the Italians. But I can only insist on them if they result in concrete benefits.' (i Die Welt, 11.1.12). Både Frankrig og Italien skruede yderligere op for presset forud for EU-topmødet i slutningen af juni 2012. Begge lande fremsatte krav om øget hjælp for at undgå insolvens inden for kort tid, samtidig med at de genfremsatte deres ønsker om at skabe euro-obligationer på længere sigt (Spiegel Online, 28.06.12, 29.06.12).

Som følge af dette pres begyndte Tyskland at signalere, at de i princippet kunne acceptere mere permanente overførsler, men kun hvis der kom væsentlig mere politisk union, især i form af langt stærkere begrænsinger på landenes muligheder for at føre selvstændig finanspolitik (EU Observer, 26.01.12, 17.05.12; Euractiv, 05.09.12; Spiegel Online, 27.08.12).

I forbindelse med EU-topmødet i juni 2012 accepterede Tyskland, at ESM-pengene kunne bruges til at redde de kriseramte landes banker, på betingelse af at ECB oprettede en fælles banktilsynsmyndighed (Spiegel Online, 29.06.12). Tyskland accepterede også, at en forhandlingsproces, der kunne føre mod en dybere økonomisk union, blev indledt. EU-topmødet i juni 2012 inviterede det Europæiske Råds formand van Rompuy til i en rapport at undersøge mulige veje mod en 'genuine' økonomisk og monetær union. Her blev der både nævnt 
en fælles indskudsgaranti for banker koblet sammen med et fælles finanstilsyn under ECB og muligvis andre mekanismer. Samtidig gentog Merkel kravet om, at der skulle være stærkere regler før flere overførsler særlig i form af mere kontrol med landenes budgetter. Først når det var indført, kunne der snakkes om kollektivisering af gæld og andre permanente tiltag (Spiegel Online, 27.06.12, 28.06.12, 12.11.12).

Diskussionerne resulterede i en rapport fra van Rompuy i december 2012 (van Rompuy, 2012) samt et parallelt tankepapir fra Kommissionen (Commission, 2012). Van Rompuys papir fremsatte et forslag om et tre-trins proces, hvor der i første fase i 2013 skulle arbejdes både for færdiggørelse af stramningerne for reglerne for landenes finanspolitiske opførsel (two-pack-lovgivning), men sideløbende med indførelse af en vis form af overførsel igennem en fælles bankgaranti. Anden fase i 2013 og 2014 vil fokusere mest på 'temporary and targeted' former for overførsler for at hjælpe lande ramt af asymmetriske chok til at kunne gennemføre strukturelle reformer, mens tredje fase vil færdiggøre pakken ved at etablere mere permanente former for overførsler, f.eks. igennem en slags forsikringsordning som landene ramt af asymmetriske chok kunne trække på, koblet med reformer af reglerne $\mathrm{i}$ form af en stigende koordinering og kontrol med nationale finanslove. Kommissionens rapport var endnu mere ambitiøs og foreslog etablering af en autonom eurozone-finanslov, som var stor nok til at hjælpe euroen til at absorbere og modstå asymmetriske chok, sammen med en vis kollektivisering af statsgælden i form af euro-obligationer (Commission, 2012).

Det videre forløb er stadig usikkert, mht. hvor ambitiøse former for overførsler og yderligere stramninger der vil blive vedtaget. Men euro-landenes modtagelse af de to rapporter ved topmødet i december 2012 giver et fingerpeg om, at vi ikke skal forvente flere væsentlige reformer, så længe der ikke er et stærkt markedspres på euro-taberne. I løbet af efterår 2012 faldt renten på statsobligationer i både Italien og Spanien til mere moderate niveauer, bl.a. pga ECB's markedsoperationer, samt spæde tegn på, at det går lidt bedre med disse landes $ø$ konomier. Det lettede markedspresset, med det resultat at både van Rompuys og Kommissionens rapporter blev forbigået i stilhed ved topmødet. Særlig overraskende er det, at van Rompuys rapport, som skulle danne dagsorden for mødet, blev slet ikke nævnt i konklusionerne (EUCO 205/12, 14.12.2012).

Derfor er konklusionen, at vi kan først forvente flere større reformer af euroen, når/hvis der igen komme et stærkt markedspres på euro-taberne, som er så alvorligt, at euro-taberne kan bruge det til at presse euro-vinderne til at acceptere flere og større overførsler (f.eks. i form af euro-obligationer). Komparative erfaringer fra andre valutaunioner understøtter denne konklusion, hvor vi har set, at større overførelsesmekanismer kun bliver indført, når der virkelig ikke er anden udvej. Dvs. hvis en eller flere af de større euro-tabere kommer i så store politiske og økonomiske vanskeligheder, at eurozonen har valget mellem enten at acceptere f.eks. at udstede en vis mængde euro-obligationer, eller at landet går bankerot med dertilhørende kollaps af eurozonen. Vi ser, at det i både Canada og USA var den store depression, som gjorde det politisk muligt at indføre disse overførsler (Bordo, Jonung and Markiewicz, 2011; Smith, 2006). Hvis vi ser på EU, er der også en del, der tyder på, at krisen ikke er helt over. Særlig situationen i Spanien er bekymrende, med over 25 pct. arbejdsløse, store massedemonstrationer mod nedskæringer og nedadgående økonomisk aktivitet; alle disse ting sætter spørgsmålstegn ved, om landets politiske system kan holde til fortsat euromedlemskab i sin nuværende form. Hvis dette på et tidspunkt slår igennem igen i form af stigende markedspres, kan vi forvente, at van Rompuys og Kommissionens papirer vil blive støvet af og igen vil danne dagsorden for videre forhandlingerne om euroens fremtid.

\section{Konklusionen}

Denne artikel har argumenteret, at diskussionerne om at reformere euroen bærer præg af issue-linkage, hvor to parter (euro-tabere og vindere) ønsker henholdsvis øgede overførsler for at hjælpe landene i krise til at tilpasse sig og strammere regler for at undgå, at alle euro-landene hæfter for den gæld, som euro-taberne har oparbejdet. I løbet af 2011 og 2012 er der sideløbende blevet forhandlet om disse to emner, hvilket har resulteret i vedtagelse af større stramninger for landenes finanspolitiske opførsel (sixpack og Finanspagten), men også visse former for midlertidige overførsler for at hjælpe lande, som er hårdt ramt af asymmetriske chok (f.eks. ESM, samt accept af ECB's aktiviteter). Tyskland var magtfuld i forhandlingerne af stramninger af reglerne (særlig Finanspagten), kun på grund af at de to emner var kædet sammen. Tyskland havde veto-magt over enhver form for overførsel grundet at dette vil være største bidragsyder til enhver form for overførsel. Denne veto-magt udnyttede Tyskland til at presse igennem 'deres' Finanspagt, men for dette var landet tvunget til at give sig på spørgsmålet om overførsler. Euro-taberne udnyttede markedspresset på dem til at få Tyskland til at acceptere sammenkobling, hvor de kunne argumentere for, at uden flere overførsler vil euroen bryde sammen.

Diskussionen om endnu mere vidtgående reformer er stadig på dagsordenen, hvilket også har karakter af en 'noget for noget'-forhandling, hvor der på overførselssi- 
den snakkes om bankunioner og euro-obligationer, mens særlig Tyskland fremhæver en form for politisk union, hvor landene accepterer endnu større begrænsninger på deres nationale budgetter som pris for flere overførsler. Grundet lettelse af markedspresset i efteråret 2012 er forhandlingerne gået i stå i slutningen af 2012, og der kan kun forventes flere reformer af både reglerne og overførsler, hvis/når markedspresset stiger igen.

Historisk har det vist sig, at 'noget for noget' forhandling inden for EU er grunden til, at større reformer er blevet vedtaget. I Maastricht-forhandlingerne repræsenterede Frankrig og Tyskland to modsatrettede positioner inden for mange emner (supranational vs. intergovernmental EU, stærkere EU vs. Status quo). Resultatet blev et større kompromis mellem disse to positioner. EU-forhandlingerne fungerer derfor kun, når Frankrig og Tyskland er på hver sin side i de større konflikter, og hvor et fransk-tysk 'noget for noget'-kompromis kan spænde bro mellem positionerne. Eller sagt med andre ord, så længe de repræsenterer hver sin side af en politisk konflikt, og issue-linkage er mulig, er fransk-tysk uenighed godt for EU.

\section{Noter}

1. Bemærk, at der argumenteres for de mere langsigtede tab/gevinster, og ikke de kortsigtede gevinster som lavere renteniveau, hvilket landene i periferien nød godt af i euroens første år.

2. Artiklen fokuserer på de strukturelle ubalancer i eurosystemet og ikke på de specifikke problemer, der er opstået pga. Grækenlands medlemskab af euroen.

3. The Economist beregnede $i$ august 2012, at hvis de fire mest sårbare euro-tabere udtrådte af euroen, vil det samlede tab for alle eurolande være omkring 1.155 mia. euro (Economist, 11.08.12). Dette svarer til ca. 12 pct. af eurozonens samlede BNP for 2011.

4. Der er naturligvis allerede overførsler mellem de rige og fattige EU-lande i form af Strukturfondene, men beløbene her er nærmest forsvindende små i forhold til behovet for overførsler, der stabiliserer situationen i underskudslandene.

\section{Referencer}

Blanchard, Olivier Jean and Lawrence F. Katz (1992) 'Regional Evolutions.', Brookings Papers on Economic Activity, 1:1992.

Bordo, Michael D., Lars Jonung and Agnieszka Markiewicz (2011) 'Does the euro need a fiscal union? Some lessons from history.', Working paper.

Commission (2012) 'A blueprint for a deep and genuine economic and monetary union - Launching a European Debate.', Brussels, 30.11.2012, $\operatorname{COM}(2012) 777$ Final/2.

Conceicao-Heldt, Eugenia (2008) 'Assessing the Impact of Issue Linkage in the Common Fisheries Policy.', International Negotiation, 13: $285-300$.

Darvas, Zsolt (2010) 'Fiscal Federalism in Crisis: Lessons for Europe from the US.', Bruegel Policy Contribution, Issue 2010/07, July 2010.
De Grauwe, Paul and Yuemei Ji (2012) 'What Germany should fear most is its fear: An analysis of Target 2 and current account inbalances.', CEPS Working Document, No. 368, 12 September 2012.

Deutsche Bank (2011) 'Europe's hidden balance-of-payments crisis.', Reports on European Integration, EU Monitor 88, October 26, 2011.

Dullien, Sebastian and Ulrike Guérot (2012) 'The Long Shadow of Ordoliberalism: Germany's Approach to the Euro Crisis.', European Council on Foreign Relations Policy Brief, 22 February 2012.

EEAG (2012) The EEAG Report on the European Economy. 'The European Balance-of-Payments Problem.', CESifo, Munich 2012: 57-81.

Eichengreen, Barry, Maurice Obstfeld and Luigi Spaventa (1990) 'One money for Europe? Lessons from the US currency union.', Economic Policy, 5(10): 117-187.

Eichengreen, Barry (1990) 'One money for Europe? Lessons from the US currency union.', Economic Policy, 5(10): 117-187.

Eichengreen, Barry (2012) 'European Monetary Integration with Benefit of Hindsight.', Journal of Common Market Studies, 50(1): 123136.

Flemming, J. Marcus (1971) 'On Exchange Rate Unification.', The Economic Journal, 81(323): 467-488.

Gillette, Clayton P. (2012) 'Fiscal Federalism as a Constraint on States.', Harvard Journal of Law and Public Policy, Vol. 35: 101-114.

Henning, C. Randall and Martin Kessler (2012) 'Fiscal Federalism: US History for Architects of Europe's Fiscal Union.', Bruegel Essay and Lecture Series.

IMF (2012) 'France 2012 Article IV Consultation.', published at http:// www.imf.org/external/np/ms/2012/102912.htm.

Ludlow, Peter (2012) 'The European Council of 8/9 December 2011.', 12 January 2012.

McKinnon, Ronald I. (2004) 'Optimum Currency Areas and Key Currencies: Mundell I versus Mundell II', Journal of Common Market Studies, 42(4): 689-715.

Moravcsik, Andrew (1998) The Choice for Europe. Ithica: Cornell University Press.

Mundell, R. A. (1961) 'A Theory of Optimum Currency Areas.', American Economic Review, 51(4): 657-665.

Sebenius, James K. (1983) 'Negotiation Arithmetic: Adding and Subtracting Issues and Parties.', International Organization, 37(2): 281316.

Sinn, Hans-Werner and Timo Wollmerschäuser (2012) 'Target loans, current account balances and capital flows: the ECB's rescue facility.', International Tax and Public Finance, 19: 468-508.

Smith, Jason Scott (2006) Building New Deal Liberalism: The Political Economy of Public Works, 1933-1956. Cambridge: Cambridge University Press.

Susskind, Lawrence (1994) Environmental Diplomacy: Negotiating More Effective Global Agreements. Oxford: Oxford University Press.

Wallis, John Joseph (1991) 'The Political Economy of New Deal Fiscal Federalism.', Economic Inquiry, XXIX: 510-524.

Wallis, John Joseph (2005) 'Constitutions, Corporations, and Corruption: American States and Constitutional Change, 1842 to 1852.', Journal of Economic History, 65(1): 211-256.

Wibbels, Erik (2003) 'Bailouts, Budget Constraints, and Leviathans: Comparative Federalism and Lessons from the Early United States.', Comparative Political Studies, 36(5): 475-508.

World Bank (2012) Doing Business in a more transparent world. Washington DC: World Bank.

van Rompuy, Herman (2012) Towards a genuine economic and monetary union. 5 December 2012. 